\title{
Most Favoured Nation Clauses:
}

\section{Towards an Assessment Framework under EU Competition Law}

\begin{abstract}
Friso Bostoen*
It is often argued that most favoured nation clauses (MFNs) should be assessed on a caseby-case basis given the perceived lack of a coherent theory guiding their assessment. This article asks whether this is the case: do we lack an assessment framework of MFNs under EU competition law? In answering this question, regard is had to both older case law and the most recent developments. Taken together, most of the issues in assessing MFNs do appear to be generally agreed upon. Moreover, legal scholarship complements the theory where the courts and authorities did leave a question open. Thus, it is offered that we are indeed well on our way to a clear assessment framework of MFNs under EU competition law.
\end{abstract}

\section{Introduction}

On 4 May 2017, the European Commission accepted commitments regarding Amazon's use of most favoured nation clauses (MFNs) in its contracts with e-book suppliers. ${ }^{1}$ This was only the latest development concerning MFNs, which were put high on the enforcement agenda by the online hotel booking cases. Diverging decisions by national competition authorities (NCAs) may have given the impression that an assessment framework for MFNs is absent. However, the Commission has been assessing MFNs for over 50 years, and NCAs have dealt with cases far beyond the realm of hotel booking.

The leading question of this article is whether we are moving towards a coherent assessment framework for MFNs under EU competition law. In solving it, we seek to weave a thread through the various developments around MFNs, distinguishing be-

\subsection{2/core/2017/3/9}

* Friso Bostoen, $\mathrm{PhD}$ researcher at the Institute for Consumer, Competition \& Market, Faculty of Law, KU Leuven (University of Leuven). For correspondence: <friso.bostoen@kuleuven.be>. Please note that all links were last accessed on 9 June 2017.

1 Commission, 'Commission accepts commitments from Amazon on e-books' (Press release, 4 May 2017) IP/17/1223 <http:// europa.eu/rapid/press-release_IP-17-1223_en.htm>.

2 For a good conceptual framework that also takes into account related clauses, see LEAR, 'Can "Fair" Prices Be Unfair? A Review of Price Relationship Agreements' (OFT Report, September 2012) 1.1-1.20; for a typology of MFNs specifically, see Francisco González-Diaz and Matthew Bennett, 'The law and economics of most-favoured nation clauses' (2015) 1 Competition Law \& Policy Debate 26, 27-28. tween the old and the new, and separating the same from the different. Instead of focusing on specific cases, we distil lessons from a large collection of cases decided by both the Commission and the NCAs. We also look beyond the case law towards more policy oriented initiatives such as the Commission's Ecommerce Sector Inquiry and its monitoring exercise in the hotel booking sector. Legal and economic scholarship corroborate the case law, and fill gaps where necessary.

The article proceeds as follows: we start by examining wholesale MFNs, which have been around for a long time (Chapter II), and then discuss retail MFNs, whose rise is closely related to the new platform economy (Chapter III). Next, we discuss the Amazon ebooks case, which brings together both kinds of MFN (Chapter IV). We then take a step back to look at broader developments around MFNs (Chapter V) and finally conclude (Chapter VI).

\section{Wholesale MFNs}

MFNs exist in all shapes and sizes, but a primary distinction can be made between wholesale MFNs and retail MFNs. ${ }^{2}$ Wholesale MFNs relate to the wholesale price of a good, and can be to the advantage of either the buyer or the seller. A clause whereby a seller agrees that a buyer will benefit from terms that are at least as favourable as those offered by the seller to any other buyer is called a most favoured customer clause (MFCC). The Commission has been dealing with such agreements since 1966, when it was 
notified of an agreement between the inventor of an electrical transmission system (A.C.E.C.) and a manufacturer of busses (Berliet). ${ }^{3}$ The agreement stipulated, amongst others, that Berliet would be allowed to use the transmission system under the conditions A.C.E.C. granted to its most favoured customer. ${ }^{4}$ Interestingly, the Commission held that this clause had neither the object nor the effect of restricting competition (as it served to protect the relation-specific investment of the companies). ${ }^{5}$ In any case, it exempted the whole agreement under Article 101(3) of the Treaty on the Functioning of the European Union (TFEU). ${ }^{6}$ In 1989, the Commission authorised another agreement containing an MFCC, this time in the coal sector. ${ }^{7}$ Finally, the Commission examined an MFCC that obliged Gazprom, a Russian energy company, to offer similar conditions to Ruhrgas as it offered to Ruhrgas's competitors in Germany. ${ }^{8}$ The Commission considered this clause restrictive under Article 101 TFEU, but closed the investigation when the companies deleted the clause.

Conversely, when the buyer agrees that a seller will benefit from terms that are at least as favourable as those offered by the buyer to any other seller, we speak of a most favoured supplier clause. Such clauses are less prevalent, but the Commission did examine them in its Hollywood studios investigation. ${ }^{9}$ These MFNs featured in 'output deals', by which the major film studios sell their entire film production to pay-TV companies for a given period of years. The clauses gave the major film studios the right to enjoy the most favourable terms agreed between a pay-TV company and any one of them. In a preliminary assessment, the Commission argued that this lead to an anti-competitive alignment of the prices, but it closed the investigation when the studios withdrew the clauses.

Thus, while being around for at least 50 years, MFNs - more specifically their wholesale variant have clearly not been a Commission enforcement priority. And probably with good reason: with regard to MFCCs, an extensive literature survey by LEAR, an economic consultancy, did 'not find any evidence that MFCCs have anticompetitive effects'. ${ }^{10}$ When the Commission did examine MFNs, they were either exempted, or the investigation was closed after withdrawal of the clauses. Moreover, the exemption cases were very fact-specific, and none of them made it up to the Court of Justice of the European Union (CJEU). Still, consistency is found in the fact that the
Commission relied on Article 101 TFEU in each of its assessments. $^{11}$

\section{Retail MFNs in Context}

The advent of online platforms brought with it a new kind of MFN, namely the retail MFN. In contrast to a wholesale MFN, a retail MFN relates to the price charged to the end-consumer. These MFNs are so connected to the platform economy that they are also called 'platform MFNs', ${ }^{12}$ which is why defining them more precisely requires us to take a closer look at the online platform business model.

\section{Online Platform Business Model}

While agreement on an exact definition of 'platform' is elusive, platforms can be described as intermediaries operating in multi-sided markets, in which they seek to facilitate interactions between different user groups (the 'sides' of the market). ${ }^{13}$ When the plat-

3 A.C.E.C./Berliet (Case IV/26045) Commission Decision 68/319/CEE [1968] OJ L201/7, 7.

4 ibid 8.

5 ibid 9; protection of investment would conventionally count as an exemption ground, but would not take away the restriction of competition.

6 ibid 9-11; the relevant provision at the time was art 85(3) of the EEC Treaty.

7 Ruhrkole AG Commission Decision 89/248/ECSC [1989] O] $\mathrm{L} 101 / 35$; the relevant provision in this case was art 65(2) of the ECSC Treaty.

8 Commission, 'Commission secures changes to gas supply contracts between E.ON Ruhrgas and Gazprom' (Press release, 10 June 2005) IP/05/710 < http://europa.eu/rapid/press-release_IP-05 -710_en.htm>.

9 Commission, 'Commission closes investigation into contracts of six Hollywood studios with European pay-TVs' (Press release, 26 October 2004) IP/04/1314 <http://europa.eu/rapid/press-release _IP-04-1314_en.htm>.

$10 \operatorname{LEAR}$ (n 2) 4.49.

11 Explicitly in all of the aforementioned MFN cases except for Hollywood studios, where it did so implicitly.

12 Andre Boik and Kenneth Corts, 'The Effects of Platform MostFavored-Nation Clauses on Competition and Entry' (2016) 59 Journal of Law and Economics 105.

13 This is how Rochet and Tirole, pioneers of multi-sided market theory, described them: Jean-Charles Rochet and Jean Tirole, 'Platform competition in two-sided markets' (2003) 1 Journal of the European Economic Association 990; they have been described similarly ever since, see eg the recent endorsements by Ofcom, the CMA and professors Clemons, Ezrachi, Strowel, Stucke and Vergoute in House of Lords Select Committee on European Union, 'Online platforms and the Digital Single Market' (Report of Session) 2016, 19. 
form facilitates interactions between suppliers and consumers, we call it a marketplace (Amazon Marketplace and eBay are prominent examples). Price comparison websites (PCWs) serve essentially the same purpose; they exist for consumer goods (eg Google Comparison Shopping) and flights (eg Momondo), but also for insurance and hotels (as we will see). The difference between the two is that PCWs bundle the existing offer of suppliers, while a marketplace may be the only place where a supplier sells its products.

The raison d'être of platforms is the presence of indirect network effects between user groups. Indirect network effects imply that 'the benefit enjoyed by a member of one group depends upon how well the platform does in attracting customers from the other group. ${ }^{14}$ In the examples cited above, the indirect network effects go both ways: suppliers on the platform will benefit from the presence of a greater number of consumers (higher demand), while consumers will appreciate more suppliers (wider range of products). This dynamic of mutual benefit may result in exponential growth, a 'positive feedback loop' making the platform dominant. ${ }^{15}$

14 Mark Armstrong, 'Competition in two-sided markets' (2006) 37 RAND Journal of Economics 668, 668.

15 German Monopolies Commission, 'Competition policy: the challenge of digital markets' (Special Report) 2015, 23-4 and 88 for an application to marketplaces; Commission, 'Online Platforms' (Staff Working Document) SWD(2016)172, 4-5 and 24 for an application to mobile ecosystems.

16 Bernard Caillaud and Bruno Jullien, 'Chicken \& egg: competition among intermediation service providers' (2003) 34 RAND Journal of Economics 309, 310; see also D Evans and R Schmalensee, 'Failure to Launch: Critical Mass in Platform Businesses' (2010) 9 Review of Network Economics 1.

17 Caillaud and Jullien (n 16) 310.

18 Indeed, Rochet and Tirole (n 13) hold that a skewed or 'nonneutral' price structure is the defining characteristic of platforms; they also offer empirical and theoretical evidence.

19 David Evans, 'The antitrust economics of multi-sided platform markets' (2003) 20(2) Yale Journal on Regulation 325, 343-7; Jean-Charles Rochet and Jean Tirole, 'Two-sided markets: a progress report' (2006) 37 RAND Journal of Economics 645, 658-60; Armstrong (n 14) 668-70; Marc Rysman, 'The economics of two-sided markets' (2009) 23 Journal of Economic Perspectives $125,129-131$

20 Caillaud and Jullien (n 16) 310; Rochet and Tirole, 'Two-sided markets: a progress report' (n 19) 651-2; additionally, charging usage fees can be a good strategy for new platforms as the price paid by the user depends solely on the success of the platform in facilitating interactions: Armstrong (n 14) 669.

21 These are also called 'across platform parity agreements' (APPAs): OECD, 'Hearing on Across-Platforms Parity Agreements' (Summary of Discussion) DAF/COMP/M(2015)2/ANN2/FINAL.
However, a new platform starts with neither suppliers nor consumers, and accordingly finds it hard to attract either. Caillaud and Jullien aptly call this conundrum the 'chicken and egg problem'. ${ }^{16}$ To solve it, they propose a 'divide-and-conquer' strategy, which consists in 'subsidizing the participation of one side (divide) and recovering the loss on the other side (conquer). ${ }^{17}$ Other authors confirm that maintaining a skewed price structure is the key to a successful platform. ${ }^{18}$ This burdens the platform operator with a choice: which user group should it subsidize, and which user group should it charge? The answer depends on a complex combination of the price elasticity of each user group, the relative strength of indirect network effects and the users' ability to multi-home (ie connect with several platforms). ${ }^{19}$ In marketplaces and PCWs, this generally leads to the supplier being charged and the consumer getting a free service.

Having chosen which side to charge and which side to subsidise, a second decision must be made: how to implement this pricing structure? In other words, how does a platform monetise the interactions it facilitates? A platform has the choice between usages fees, paid every time an interaction takes place, or membership fees, paid for getting access to the platform. If a platform can technically monitor the transaction it facilitates, it can charge user fees; if not (ie when users can bypass the platform once they found each other), then the platform must resort to membership fees. ${ }^{20} \mathrm{~A}$ marketplace can easily track each transaction, and thus imposes usage fees. PCWs are easier to bypass, as they simple bundle the offers of suppliers who sell the same product on their own website. To make sure consumers do purchase the product through the PCW, it needs to offer better terms than the supplier - which is exactly what a retail MFN guarantees.

\section{The Cases}

A retail MFN can be defined as a clause whereby a seller agrees to charge a retail price for its product on a platform that is at least as low as the prices it charges through other sales channels. ${ }^{21}$ When the seller promises to charge prices on a certain platform that are as low as the ones it charges through any other sales channel, including on other platforms, it is called a wide MFN. When the seller only commits it- 
self to charge a platform price that is lower than the one it charges on its own website, the clause is termed a narrow $M F N .^{22}$ Note that, while these definitions refer to price, retail MFNs can also concern other terms such as product range.

While the assessment of retail MFNs has often been called fact-specific, with calls for a case-by-case analysis, ${ }^{23}$ an assessment framework is gradually taking shape. The Apple e-books case was, until recently, the only Commission guidance with regard to this specific type of MFN. However, recent developments include its report on the monitoring exercise in the online hotel booking sector, the final report on its ecommerce sector inquiry, and the Amazon e-books case. ${ }^{24}$ NCAs have examined MFNs more often and even though their outcome diverges at times, their assessments offer valuable insights.

The Apple e-books case was quite fact-specific (and a commitment decision at that). ${ }^{25}$ Five large publishers were dissatisfied with Amazon's wholesale model for the distribution of e-books, which meant that Amazon would buy the e-books from the publishers and then resell them, often at a lower price. ${ }^{26}$ The publishers saw an opportunity in Apple entering the market with the launch of its iPad and complementary iBookstore, a platform to connect publishers and readers. Each of the five publishers entered into an agency agreement including a retail MFN, which allowed Apple to sell the publishers' e-books at a price that was as low as the one offered by any other retailer (including Amazon). ${ }^{27}$ On every e-book sale,
Apple would enjoy a 30\% commission fee. The Commission took the view that these clauses acted as a 'commitment device' to align the publisher's incentives to force Amazon to change from a wholesale to an agency model..$^{28}$ In turn, this generalisation of the agency model would allow the publishers to raise retail prices for e-books on a global scale. Apple and the five publishers ended up offering commitments, including a five-year ban on retail MFNs, which the Commission accepted. ${ }^{29}$

Online hotel booking platforms ('hotel portals') offer consumers the opportunity to search, compare and book hotels, while offering the hotels the possibility to showcase their rooms to a large audience. The hotel portals receive a commission fee per successful interaction, ie on every room booked through their platform. The contracts between several large hotel portals (HRS, Booking.com, Expedia) and hotels contained wide retail MFNs, prohibiting the hotels from offering their rooms at a lower price or under better conditions both on their own website and on other portals. ${ }^{30}$ On 20 December 2013, the German competition authority - the Bundeskartellamt, prohibited HRS from further implementing these clauses in Germany. ${ }^{31}$ The Bundeskartellamt rejected the commitments offered by HRS as 'a precedence effect for other cases only emanates from an explicit finding of the infringement. ${ }^{, 32}$ Such precedence effect was important as the Bundeskartellamt had recently started looking into the retail MFNs used by Booking.com and Expedia. ${ }^{33}$ The Düsseldorf Higher

22 On this distinction: Morten Hviid, 'OECD Hearing on Across Platform Parity Agreements' (Background Paper) DAF/COMP(2015)6, 20-21; Ariel Ezrachi, 'The competitive effects of parity clauses on online commerce' (2015) 11 European Competition Journal 488, 489; Silke Heinz, 'Online Booking Platforms and EU Competition Law in the Wake of the German Bundeskartellamt's Booking.com Infringement Decision' (2016) 7 JECLAP 530, 530-1; Margherita Colangelo, 'Parity Clauses and Competition Law in Digital Marketplaces: The Case of Online Hotel Booking' (2017) 8 JECLAP 3, 5; Matthias Hunold, 'Best Price Clauses: What Policy as Regards Online Platforms?' (2017) 8 JECLAP 119, 119-20.

23 Ingrid Vandenborre and Michael Frese, 'Most favoured nation clauses revisited' (2014) 35 ECLR 588, 592; Germany, 'OECD Hearing on across platform parity agreements' (Note) DAF/COMP/WD(2015)56; Colangelo (n 22) 6; contra: Volker Soyez, 'The compatibility of MFN clauses with EU competition law' (2015) 36 European Competition Law Journal 107, 107.

24 These developments are discussed under Chapter IV and V.

25 E-books (Case COMP/AT.39847) Commission Decision $\mathrm{C}(2012) 9288$; the same case was also adjudicated in the Southern District Court of New York: United States of America v. Apple Inc., et al., 12 Civ 2862 (DLC), with a similar outcome (subsequent appeals were rejected); for a discussion of the US case:

Michael Weiner and Craig Falls, 'Counseling on MFNs After ebooks' (2014) 28 Antitrust Magazine 68

26 Supposedly to boost the sales of its Kindle e-reader.

27 See E-books (n 25) para 31 for a description of the clause.

28 The publishers' margin under the agency model was even lower than under the wholesale model, but that was the point: making all of them worse off would push them to convert Amazon to an agency model by denying Amazon access to e-books (ibid paras 32 and 38).

29 ibid para 95 seq.

30 For a more detailed description of the various hotel portal cases: Colangelo (n 22) 3

31 Bundeskartellamt, Case B9-66/10, HRS-Hotel Reservation Service, 20 December 2013 (the author bases himself on the English translation provided by Booking and uploaded by the Bundeskartellamt); see OECD, 'Hearing on across platform parity agreements' (Note by Germany) DAF/COMP/WD(2015)56 for an extensive (self-)assessment.

32 Bundeskartellamt, Case B9-66/10, HRS-Hotel Reservation Service, 20 December 2013, para 14.

33 ibid para 266. 
Regional Court subsequently confirmed the HRS decision on appeal. ${ }^{34}$

At the same time, several other competition authorities were examining the retail MFNs with hotel portals, especially those of Booking.com (being the largest portal in the EU). The actions of the French, Italian and Swedish competition authorities were coordinated by the Commission. ${ }^{35}$ In April 2015, they lead to commitments which put an end to the wide MFNs but maintained the narrow MFNs. ${ }^{36}$ Thus, hotels would be free to vary their prices and conditions on the different hotel portals, but would still have to guarantee Booking.com prices and conditions that were at least as good as the ones offered on their website. $^{37}$ Two months later, Booking.com generalised these commitments throughout all of Europe, trusting 'that these changes will set the tone for an industry wide solution, ${ }^{38}$ which indeed they did when Expedia announced similar commitments only days later. ${ }^{39}$ However, these commitments did not go far enough to satisfy the Bundeskartellamt: on 23 December 2015, it ruled that even Booking.com's narrow MFNs infringe German and EU competition law. $^{40}$

A number of other cases also merit consideration. Amazon Marketplace has been investigated for its use of retail MFNs obliging sellers to offer their prod-

34 See Oberlandesgerichts Düsseldorf, 'HRS-Hotelbuchungsportal: "Bestpreisklauseln" kartellrechtswidrig und damit unzulässig' (Press release, 9 January 2015) <http://www.olg-duesseldorf.nrw de/behoerde/presse/archiv/Pressemitteilungen_aus 2015/ 20150109_PM_HRS_Entscheidung/>; Bundeskartellamt, 'HRS's "best price" clauses violate German and European competition law - Düsseldorf Higher Regional Court confirms Bundeskartellamt's prohibition decision' (press release, 9 January 2015 <http://www.bundeskartellamt.de/SharedDocs/Meldung/EN/ Pressemitteilungen/2015/09_01_2015_hrs.html>.

35 On this coordinating role, see Commission, 'Commission announces the launch of market tests in investigations in the online hotel booking sector by the French, Swedish and Italian competition authorities' (Press release, 15 December 2014) IP/14/2661 $<$ http://europa.eu/rapid/press-release_IP-14-2661_en.htm>.

36 Konkurrensverket, Decision 596/2013, Booking.com, 15 April 2015; Autorité de la concurrence, Decision 15-D-06, Booking.com, 21 April 2015; Autorità Garante della Concorrenza e del Mercato, 'Commitments offered by Booking.com: closed the investigation in Italy, France and Sweden' (Press release, 21 April 2015) <http://www.agcm.it/en/newsroom/press-releases/2207>.

37 Moreover, hotels would also be allowed to charge lower prices (and offer better conditions) through their offline sales channel (ie in the lobby, on the telephone) and within the framework of their loyalty programme. Booking.com has also undertaken not to apply equivalent measures. The commitments would apply for a period of five years.

38 Booking.com, 'Booking.com to Amend Parity Provisions Throughout Europe' (Press release, 25 June 2015) <https://news.booking.com/ bookingcom-to-amend-parity-provisions-throughout-europeesp $>$. ucts at the most favourable price via Amazon Marketplace compared to any other online sales channel (ie a wide MFN). When Amazon decided to end this policy, both the UK Competition \& Market Authority (CMA) and the Bundeskartellamt closed their investigations. ${ }^{41}$ The Bundeskartellamt closed another investigation when Verivox, a PCW for the supply of electricity and gas, vowed to stop using retail MFNs. ${ }^{42}$ The CMA, finally, examined MFNs used by PCWs for car insurance when it was investigating the sector. The CMA prohibited the use of wide MFNs, but allowed the PCWs to continue using narrow MFNs. ${ }^{43}$

A first observation is that competition authorities consistently rely on Article 101 TFEU to assess retail MFNs. A clear trend (but with exception by the Bundeskartellamt) is the authorities' permission of narrow retail MFNs but prohibition of wide retail MFNs. While competition authorities (largely) come to the same conclusions, the next title checks whether they also take the same road there.

\section{The Questions}

When assessing retail MFNs under Article 101 TFEU, four questions stand out. First of all, are we dealing

39 Expedia, 'Expedia Amends Rate, Conditions and Availability Clauses' (Press release, 1 July 2015) <http://www.expediainc .com/news-release $/$ ?aid $=123242 \&$ fid $=99 \& y y=2015>$.

40 Bundeskartellamt, Case B 9-121/13, Booking.com, 23 December 2015 (the author bases himself on the English translation provided by the Bundeskartellamt); see Heinz (n 22) for an assessment.

41 Bundeskartellamt, 'Amazon announces end to price parity' (Press release, 27 August 2013) <http://www.bundeskartellamt.de/ SharedDocs/Meldung/EN/Pressemitteilungen/2013/27_08_2013 Amazon-Preisparität.html> and Bundeskartellamt, 'Amazon abandons price parity clauses for good' (Press release, 26 November 2013) <http://www.bundeskartellamt.de/SharedDocs/ Meldung/EN/Pressemitteilungen/2013/26_11_2013_Amazon -Verfahrenseinstellung.html>; on the proceedings in the UK, see Office of Fair Trading, 'OFT welcomes Amazon's decision to end price parity policy' (Press release, 29 August 2013) < http:// webarchive.nationalarchives.gov.uk/20140402142426/http:/www .oft.gov.uk/news-and-updates/press/2013/60-13>; see also ECN, 'Germany and United Kingdom: Antitrust Cases against Amazon formally closed' (Brief, December 2013), 5 <http://ec.europa.eu/ competition/ecn/brief/05_2013/brief_05_2013.pdf>.

42 Bundeskartellamt, "Verivox vows to stop using "best price" clauses' (Press release, 3 June 2015) <http://www.bundeskartellamt.de/ SharedDocs/Meldung/EN/Pressemitteilungen/2015/03_06_2015 _Verivox.html>

43 Competition \& Market Authority, 'Private motor insurance market investigation' (Final report) 2014; Competition \& Market Authority, 'Private motor insurance market investigation' (Order) 2015, 4.1-4.2. 
with a vertical or horizontal agreement (or maybe even something else)? Secondly, do these clauses restrict competition by object or by effect? Thirdly, can they be exempted under the Vertical Block Exemption Regulation (VBER)? If not, can they benefit from an individual exemption under Article 101(3) TFEU? These questions are considered in turn; the answers are drawn from the collection of case law discussed above, while doctrine is used to corroborate and to fill gaps.

\section{a. Horizontal, Vertical or Agency Agreement?}

In the aforementioned cases, MFNs were generally assessed as vertical agreements, which allows for application of the VBER, but there have been two exceptions. In the Apple e-books case, the Commission did not explicitly qualify the agreement as either vertical or horizontal, but it is worth noting that it did not discuss the applicability of the VBER ${ }^{44}$ In the equivalent case on the other side of the Atlantic, the judge was more straightforward, holding that 'Apple participated in and facilitated a horizontal price-fixing conspiracy' and as a result committed a per se violation of the Sherman Act. ${ }^{45}$ In the Amazon Marketplace case, then, the Bundeskartellamt treated the MFN as a horizontal agreement, the reason being that Amazon both manages the platform and offers its own goods on the platform. ${ }^{46}$ In other words, qualifying the MFN as horizontal was justified because Amazon agreed on it with its direct competitors, ie the suppliers on its platform. The exception only confirms the rule that MFNs are generally vertical agreements.

44 The Commission did consider the applicability of art 101(3) TFEU (and 53(3) of the EEA Agreement), but held that they did not apply 'because the cumulative conditions set out in those provisions are not met': E-books (n 25) para 94.

45 United States of America v Apple Inc (n 25) 120; the judge added: 'If it were necessary to analyze this evidence under the rule of reason, however, the Plaintiffs would also prevail'.

46 Bundeskartellamt, Case B6-46/12, 'Amazon beseitigt die Verpflichtung zur Preisparität für Händler auf dem Amazon Marketplace' (Fallbericht, 9 December 2013), describing Amazon Marketplace as an 'integrierte Plattform'.

47 Commission Guidelines on Vertical Restraints [2010] OJ C130/1, para 18.

48 Addressing this issue from a broader angle, see P Goffinet and F Puel, 'Vertical Relationships: The Impact of the Internet on the Qualification of Agency Agreements' (2015) 6 JECLAP 242; contra: arguing that Article 101(1) is inapplicable because of the existence of an agency agreement, see Pinar Akman, 'A competition law assessment of platform most-favored-customer clauses'
The horizontal/vertical dichotomy has also been questioned given the specific nature of platforms. They do not usually compete with their suppliers, but are not in a conventional distributor relationship either (they do not resell anything). Could the platform operator be considered an agent of the suppliers that make use of the platform? In that case, according to the Commission's Guidelines on Vertical Restraints, the MFNs embedded in the agency agreement may fall outside of the scope of Article 101(1) TFEU. ${ }^{47}$ The agency argument has intuitive appeal as many platforms do operate a so-called 'agency model', where the supplier determines the price and the platform sets the commission fee. It has been pleaded by HRS, but was rejected by the Bundeskartellamt for two reasons. ${ }^{48}$ Firstly, the Guidelines specify that only 'obligations imposed on the agent' fall outside of the scope of Article 101(1) TFEU. ${ }^{49}$ Conversely, MFNs are imposed on the supplier, ie the principal. ${ }^{50}$ Secondly, the agent may not bear the financial or commercial risk of its activities. ${ }^{51}$ Platforms, however, are subject to extensive economic risks such as the investments in platform development, advertising and contractual networks. $^{52}$

\section{b. Anticompetitive Object or Effect?}

Are retail MFNs anticompetitive by object or by effect? Again, the competition authorities' practice shows consistency: retail MFNs have always been assessed as restrictions of competition by effect, ${ }^{53}$ except when the effects were primarily horizontal (the Apple e-books and Amazon Marketplace cases), in

(2016) 12 Journal of Competition Law and Economics 781, 804-814

49 Commission Guidelines on Vertical Restraints, para 18.

50 Bundeskartellamt, Case B9-66/10, HRS-Hotel Reservation Service, 20 December 2013, para 147.

51 Commission Guidelines on Vertical Restraints, paras 13-7.

52 Bundeskartellamt, Case B9-66/10, HRS-Hotel Reservation Service, 20 December 2013, paras 148-9, where it also notes that this reasoning is in line with the ECJ's qualification of travel agents: Case C-311/85 Vereniging van Vlaamse Reisbureaus EU:C:1987:418 [1987] ECR I-3801.

53 There is some ambiguity in the Bundeskartellamt's decisions on hotel portals as it sought to leave open the possibility to qualify retail MFNs as by object restrictions. However, it still clearly treated the MFNs as restrictions of competition by effect, see Bundeskartellamt, Case B9-66/10, HRS-Hotel Reservation Service, 20 December 2013, para 152, where it states: 'Even though it may be arguable that the MFN clauses of HRS do not bring about restraints of competition by object, they do at least bring them about by effect'. 
which case a by object qualification was appropriate. ${ }^{54}$ Competition authorities have focused on two main effects of retail MFNs, namely softening retail price competition and creating barriers to entry. ${ }^{55}$

First of all, retail MFNs restrict competition between platforms. ${ }^{56}$ The result of these MFNs is that the supplier is prevented from offering its product at a lower price on any other platform than the one favoured by the clause. For the favoured platform, this essentially means that the final price is disconnected from the height of the commission rate: when the platform increases its commission, the final price will have to stay lower than on any other platform. In other words, the MFN removes the economic incentive of the platform to offer a lower commission rate and even creates an incentive to increase it. The supplier also cannot effectively penalise the platform for increasing its commission. The supplier could only increase the final price, but would then have to do so on every competing platform too, thereby making its product less attractive. In fact, the MFN even removes the economic incentive of competing platforms to lower their commission, as such a move would not translate into a lower price to consumer: the price on their platform would have to remain higher than on the favoured platform. Competitive advances by other portals are thus blocked. In sum, retail MFNs prevent competition on commission fees, thereby leading to higher prices for consumers.
Secondly, retail MFNs create barriers to entry impeding the market access of new platforms. ${ }^{57}$ The problem is that a new platform will not be able to differentiate itself from incumbents by charging lower commissions. These lower rates could not be passed on to consumers as the supplier is forced to keep its price lower on the favoured platform, even when that platform demands a substantially higher commission. Even innovative, efficient new platforms will thus find it hard to penetrate the market as they cannot offer the consumers better terms than the incumbent, favoured platform.

While competition authorities unanimously agree on these effects in the case of wide MFNs, there is some debate on their importance in the case of narrow MFNs. Such MFNs do not require price parity between different platforms, but only between the favoured platform and the supplier's own website. Accordingly, they allow for effective competition between platforms with regard to commissions. ${ }^{58}$ Competition authorities often only discuss narrow MFNs when considering commitments (supra) or possible exemptions (infra), but it is sometimes questioned whether they are restrictive at all. The Swedish Competition Authority held in its hotel booking decision:

Booking.com and the hotels are in a vertical relationship and $[. .$.$] are not active in the same rele-$ vant market. Thus, according to the Competition Authority's assessment, the vertical price parity

(Final report) 2014, paras 8.40-8.43 and 8.72-8.79 (for evidence); Konkurrensverket, Decision 596/2013, Booking.com, 15 April 2015, paras 21-2; Autorité de la concurrence, Decision 15D-06, Booking.com, 21 April 2015, paras 115-22 and 127-131; Autorità Garante della Concorrenza e del Mercato, 'Commitments offered by Booking.com: closed the investigation in Italy, France and Sweden' (Press release, 21 April 2015) < http://www .agcm.it/en/newsroom/press-releases/2207>; Bundeskartellamt, 'Verivox vows to stop using "best price" clauses' (Press release, 3 June 2015) <http://www.bundeskartellamt.de/SharedDocs/ Meldung/EN/Pressemitteilungen/2015/03_06_2015_Verivox.html $>$.

57 ECN, 'Germany and United Kingdom: Antitrust Cases against Amazon formally closed' (Brief, December 2013), 5 <http://ec .europa.eu/competition/ecn/brief/05_2013/brief_05_2013.pdf>; Bundeskartellamt, Case B9-66/10, HRS-Hotel Reservation Service, 20 December 2013, paras 160-3; Competition \& Market Authority, 'Private motor insurance market investigation' (Final report) 2014, paras 8.35-8.39 and 8.69-8.71 (for evidence); Konkurrensverket, Decision 596/2013, Booking.com, 15 April 2015, para 23; Autorité de la concurrence, Decision 15-D-06, Booking.com, 21 April 2015, 123-31.

58 Extensively on the difference between wide and narrow MFNs: Ezrachi (n 22) who concludes (on p. 507): 'Narrow parity [...] does not give rise to many of the concerns linked to wide parity'. 
does not restrict any competition between Booking.com and the hotels. ${ }^{59}$

In the same sense, the Competition \& Markets $\mathrm{Au}$ thority found in its car insurance market investigation that 'the restriction on competition imposed by a narrow MFN was unlikely to be significant' as competition essentially takes place between the different PCWs, and not between PCWs and the suppliers' websites. $^{60}$

The Bundeskartellamt takes an opposing stance, holding in its HRS decision that 'MFN clauses restrict the price setting on hotel rooms across the entire Internet. ${ }^{\prime 1}$ As hotels do not pay a commission on bookings made through their own website, they could offer a lower price than through a platform, but narrow MFNs prevent this. ${ }^{62}$ While the HRS decision was mainly concerned with wide MFNs, the Bundeskartellamt examined only narrow MFNs in its Booking.com decision. The Bundeskartellamt repeated that the narrow MFNs eliminate price competition between portals and the hotels' own website, ${ }^{63}$ but it also goes further with a theory captured well by Heinz:

In essence, the [Bundeskartellamt] finds that the narrow MFN clauses have the same restrictive effects as the wide ones, including on competition among portals, based on the assumption/finding that hotels would have no incentive to offer lower prices on other portals than on their own website. ${ }^{64}$

The important point is, however, that MFNs are assessed as restrictions of competition by effect. ${ }^{65}$ Wide

59 Konkurrensverket, Decision 596/2013, Booking.com, 15 April 2015, para 25 .

60 Competition \& Market Authority, 'Private motor insurance market investigation' (Final report) 2014, paras 8.46-8.68.

61 Bundeskartellamt, Case B9-66/10, HRS-Hotel Reservation Service, 20 December 2013, para 172.

62 ibid para 170.

63 Bundeskartellamt, Case B 9-121/13, Booking.com, 23 December 2015, paras 229-36.

64 Heinz (n 22) 535.

65 Notably on this point, see Ingrid Vandenborre and Michael Frese, 'The Role of Market Transparency in Assessing MFN Clauses' (2015) 38 World Competition 333, 337-338; Akman (n 48) 821-823; however, some authors would like wide MFNs to be treated as by object restrictions, see Fletcher and Hviid (n 55) 71.

66 Commission Regulation (EU) No 330/2010 of 20 April 2010 on the application of Article 101(3) of the Treaty on the Functioning of the European Union to categories of vertical agreements and concerted practices [2010] OJ L102/1, arts 2, 3 and 4 .
MFNs are unanimously considered to constitute such a restriction. The fact that the Bundeskartellamt also focusses on the anti-competitive effects of narrow MFNs is, in itself, not a real deviation from established theory. As noted, most competition authorities (at least implicitly) find narrow MFNs to be restrictive - the real question is whether they are subsequently exempted.

\section{c. Exemption under the Vertical Block Exemption Regulation}

The VBER determines that a vertical agreement can be exempted from the application of Article 101(1) TFEU on the condition that the market share of neither of the parties exceeds 30\% and the agreement does not contain a 'hardcore restriction'.66

The first condition, ie the market share threshold, must evidently be considered on a case-by-case basis. Apart from the $30 \%$ limit, the Regulation is also inapplicable 'where parallel networks of similar vertical restraints cover more than $50 \%$ of a relevant market. ${ }^{67}$ The scrutiny is thus stricter in markets where MFNs are widespread, such as in the online hotel booking sector. ${ }^{68}$ In that case, even when both the platform and the supplier hold a market share of less than $30 \%$, the agreement may not benefit from the block exemption.

When it comes to defining the relevant market, a separate platform market is usually identified. ${ }^{69}$ In most cases, the competition authority concluded that the platform under scrutiny holds a share of over $30 \%$ on that market. ${ }^{70}$ This means that the second
67 ibid art 6

68 See Autorité de la concurrence, Decision 15-D-06, Booking.com, 21 April 2015, paras 135-9.

69 Bundeskartellamt, Case B9-66/10, HRS-Hotel Reservation Service, 20 December 2013, paras 69-107; Competition \& Market Authority, 'Private motor insurance market investigation' (Final report) 2014, paras 4.24-4.34; Konkurrensverket, Decision 596/2013, Booking.com, 15 April 2015, para 15-17; Autorité de la concurrence, Decision 15-D-06, Booking.com, 21 April 2015 , paras 95-102 (also including online travel agencies); Bundeskartellamt, Case B 9-121/13, Booking.com, 23 December 2015, paras 135-51.

70 Bundeskartellamt, Case B9-66/10, HRS-Hotel Reservation Service, 20 December 2013, paras 188-95; Konkurrensverket, Decision 596/2013, Booking.com, 15 April 2015, para 18; Autorité de la concurrence, Decision 15-D-06, Booking.com, 21 April 2015 paras 103-11; Bundeskartellamt, Case B6-46/12, 'Amazon beseitigt die Verpflichtung zur Preisparität für Händler auf dem Amazon Marketplace' (Fallbericht, 9 December 2013); Bundeskartellamt, Case B 9-121/13, Booking.com, 23 December 2015, paras 251-4. 
question of whether retail MFNs constitute hardcore restrictions has remained unanswered. ${ }^{71}$ The Bundeskartellamt may soon be forced to answer this question when it concludes its investigation into Expedia, which has a share of only $10-15 \%$ on the German hotel portal market. ${ }^{72}$

Until then, guidance must be sought elsewhere. The question is whether retail MFNs constitute a hardcore restriction under Article 4(a) VBER, ie whether they are a form of resale price maintenance $(\mathrm{RPM}){ }^{73}$ In its Guidelines, the Commission writes that RPM can be achieved by indirect means such as 'linking the prescribed resale price to the resale prices of competitors, ${ }^{\prime 7}$ which does seem to capture the retail MFN mechanism. However, it further specifically addresses MFNs, describing them as a 'supportive' measure for RPM. ${ }^{75}$ The doctrine has also weighed in on the question, and can be split up in two camps.

A first group of authors qualifies retail MFNs as a form of RPM. This group notably includes Fletcher and Hviid, who argue that wide retail MFNs are 'RPM at its worst. ${ }^{76}$ The reasoning goes that MFNs have a vertical element, whereby a supplier sets final retail prices, but also a horizontal element, whereby the supplier sets identical retail prices across all platforms. As this horizontal element gives rise to the most serious antitrust concerns, and is particularly strong with wide retail MFNs, they are the worst kind of RPM. ${ }^{77}$ This is in line with the UK's contribution to the OECD Roundtable on online vertical restraints, which noted:

[R]etail-price MFNs have the potential to exacerbate the possible harm from RPM by explicitly in- troducing a horizontal element to an otherwise vertical agreement - the retail price set for one retailer is conditioned on the retail price set for other retailers. $^{78}$

A second group does not consider retail MFNs a form of RPM. While they generally accept the horizontal effects of MFNs, they plead against their qualification as hardcore restrictions. Article 4(a) VBER determines that vertical agreements cannot benefit from the block exemption when they have as their object the restriction of the buyer's ability to determine its sale price by the supplier. However, in a retail MFN scenario, the platform is best qualified as the buyer, and its freedom to set prices is not restrained. It is rather the supplier whose ability to set prices is restricted, but this is not captured by the provision. ${ }^{79}$ Additionally, it is argued that even the suppliers remains free to set their prices, as long as the product is not offered cheaper on a different platform. ${ }^{80} \mathrm{In}$ other words, MFNs set a relative rather than an absolute price level..$^{81}$

While the Bundeskartellamt left the question open in the end, it did weigh the arguments. In line with the second group of authors, it held that ' $[\mathrm{i}] \mathrm{f}$ the wording is interpreted strictly, the conditions of Art. 4 (a) of the Vertical Restraints Block Exemption Regulation are not fulfilled, ${ }^{82}$ On the other hand, the Bundeskartellamt argued that retail MFNs did 'have the de facto effect of minimum prices.' ${ }^{83}$ While this question remains unanswered, competition authorities were more generous with their guidance on the possibility of an individual exemption.
71 Except for, as noted supra, in the Bundeskartellamt's Amazon Marketplace investigation. In that case the MFN was qualified as a hardcore restriction, but this was due to its specific, horizontal nature.

72 See Bundeskartellamt, Case B 9-121/13, Booking.com, 23 December 2015, para 69 on the proceedings and 243 on the market share.

73 Commission Regulation (EU) No 330/2010 of 20 April 2010 on the application of Article 101(3) of the Treaty on the Functioning of the European Union to categories of vertical agreements and concerted practices [2010] OJ L102/1, art 4(a); Commission Guidelines on Vertical Restraints, para 48.

74 Commission Guidelines on Vertical Restraints, para 48

75 ibid; Vandenborre and Frese consider this an argument against the analogy between MFNs and RPM: Vandenborre and Frese, 'The Role of Market Transparency in Assessing MFN Clauses' (n 65) $336-337$

76 Fletcher and Hviid (n 55)
77 ibid 70, 88 and 96-97.

78 United Kingdom, 'Policy Roundtable on Vertical Restraints for On-line Sales' (Written Submission) DAF/COMP(2013)13, 149; also making the connection: L Atlee and Y Botteman, 'Resale Price Maintenance and Most-Favored Nation Clauses: The Future Does Not Look Bright' (2013) 1 CPI Antitrust Chronicle 2, 7.

79 Soyez (n 23) 109; Akman (n 48) 820-1; contra: D Zimmer and M Blaschczok, 'Most-favoured-customer clauses and two-sided platforms' (2014) 5 JECLAP 187, 193.

80 Paolo Buccirossi, 'Policy Roundtable on Vertical Restraints for On-line Sales' (Background Note) DAF/COMP(2013)13, 23.

81 Pinar Akman and Daniel Sokol, 'Online RPM and MFN Under Antitrust Law and Economics' (2017) 50 Review of Industrial Organization 133, 138.

82 Bundeskartellamt, Case B9-66/10, HRS-Hotel Reservation Service, 20 December 2013, para 183.

83 ibid para 185. 


\section{d. Exemption under Article 101(3) TFEU}

When the market share of one of the parties to the vertical agreement exceeds 30\%, it may still be 'individually' exempted under Article 101(3) TFEU. This can even be the case when the agreement contains a hardcore restriction, although there is a presumption that such an agreement does not fulfil the conditions of Article 101(3) TFEU. ${ }^{84}$ To benefit from the exemption, the restrictive agreement must generate efficiencies that benefit consumers, while the restraint must be indispensable and may not eliminate competition. When it comes to applying these conditions to MFNs there is a division between most European competition authorities, which hold that narrow (but not wide) MFNs can be exempted, and the Bundeskartellamt, which does not even consider narrow MFNs exemptible.

A preliminary question is which efficiencies have to be taken into account. The Commission Guidelines require that 'the efficiencies result from the economic activity that forms the object of the agreement. ${ }^{85}$ As the economic activity of platforms consists in intermediation, the efficiencies are great: they significantly lower search costs and increase price transparency for consumers (which in turn enhances competition). ${ }^{86}$ The Bundeskartellamt, however, looks only at the efficiencies generated by the restriction itself, ie the MFN; ${ }^{87}$ a position that appears overly strict. $^{88}$

The issue that retail MFNs try to solve is free-riding. The fear is that consumers would visit the platform to see what is on offer (taking advantage of the low search costs and price transparency), but would subsequently visit the preferred supplier's own website to buy the product. ${ }^{89}$ This goes back to the platform business model: they charge a fee on every transaction through the platform (ie a usage fee), so when those transactions happen outside of the platform, they do not get paid. In that case, the suppliers are free-riding on the platform's investment (which consists of the development and management of the platform, and advertising). Of course, a consumer would only be incentivized to conclude the transaction on the supplier's own website if it offered a lower price, which is exactly what narrow retail MFNs prevent.

Having assessed the efficiencies of the economic activity and their benefit to consumers, the next question is whether the restriction is indispensable. Even the Bundeskartellamt implicitly accepts that narrow
MFNs are necessary to support the current business model of platforms, but it argues that other business models are possible. ${ }^{90}$ One option would be to charge consumers instead of suppliers through a membership or usage fee. Another option would be to keep charging suppliers but through pay-per-click fees (generally used in advertising platforms) instead of per-transaction fees. Given the specificity of the platform business model, such changes are far-reaching. They belong to the realm of 'hypothetical or theoretical alternatives' that the Commission does not require undertakings to consider. ${ }^{91}$ Finally, narrow MFNs do not eliminate competition: they allow for competition (on commissions) between the different platforms. ${ }^{92}$

In line with other competition authorities, it is therefore recommended to accept narrow MFNs as a way to safeguard the efficiencies generated by platforms. $^{93}$

\section{Conclusion}

The foregoing survey of case law, whose essence was distilled per legal issue, allows us to conclude that we

84 Commission Guidelines on Vertical Restraints, paras 47 and 60-4.

85 Commission Guidelines on the application of Article 81(3) of the Treaty [2004] OJ C101/97, para 53.

86 Competition \& Market Authority, 'Private motor insurance market investigation' (Final report) 2014, 8.108-8.115; Konkurrensverket, Decision 596/2013, Booking.com, 15 April 2015, para 27; see also Bundeskartellamt, Case B 9-121/13, Booking.com, 23 December 2015, paras 261-5.

87 Bundeskartellamt, Case B9-66/10, HRS-Hotel Reservation Service, 20 December 2013, para 199 ('the efficiency gains brought about by the MFN clauses'); Bundeskartellamt, Case B 9-121/13, Booking.com, 23 December 2015, para 260 ('efficiency gains resulting precisely from the narrow best price clauses'), see also paras 280-1.

88 Heinz (n 22) 535

89 A practice called 'showrooming'.

90 Bundeskartellamt, Case B9-66/10, HRS-Hotel Reservation Service, 20 December 2013, paras 217-22; Bundeskartellamt, Case B 9-121/13, Booking.com, 23 December 2015, paras 286-98.

91 Commission Guidelines on the application of Article 81(3) of the Treaty [2004] OJ C101/97, para 75; discussing this, see Hunold (n 22) $123-4$.

92 Ezrachi (n 22) 507.

93 Konkurrensverket, Decision 596/2013, Booking.com, 15 April 2015, paras 28-30; Autorité de la concurrence, Decision 15D-06, Booking.com, 21 April 2015, paras 170-98; Autorità Garante della Concorrenza e del Mercato, 'Commitments offered by Booking.com: closed the investigation in Italy, France and Sweden' (Press release, 21 April 2015) <http://www.agcm.it/en/ newsroom/press-releases/2207>. 
are moving towards an assessment framework of retail MFNs under EU competition law. Retail MFNs should be assessed as vertical agreements, except in the rare case where the platform concerned is orchestrating a true conspiracy, or is thoroughly vertically integrated and thus competes with its suppliers. As MFNs are characterised by both pro- and anti-competitive effects, they should be assessed as by effect restrictions. And while MFNs may have horizontal effects similar to RPM, they cannot be qualified as hardcore restrictions under the current Article 4(a) VBER. When it comes to individual exemptions under Article 101(3) TFEU, it is noted that the pro-competitive effects of narrow MFNs will generally outweigh the anti-competitive effects, while the same cannot be said of wide MFNs. This leaves us with the situation where wide MFNs are accepted depending on whether the parties hold a market share over or under $30 \%$, but this is not an issue. Firstly, as noted in the VBER, the likelihood that the pro-competitive effects of a vertical restraint outweigh its anti-competitive ones depends on the market power of the

94 Commission Regulation (EU) No 330/2010 of 20 April 2010 on the application of Article 101(3) of the Treaty on the Functioning of the European Union to categories of vertical agreements and concerted practices [2010] OJ L102/1, consideration 7; Commission Guidelines on Vertical Restraints, paras 6 and 23.

95 Akman (n 48) 793-794.

96 Council Regulation (EC) No 1/2003 of 16 December 2002 on the implementation of the rules on competition laid down in Articles 81 and 82 of the Treaty [2003] L1/1; Vandenborre and Frese, 'The Role of Market Transparency in Assessing MFN Clauses' (n 65) 337.

97 Commission, 'Commission opens formal investigation into Amazon's e-book distribution arrangements' (Press release, 11 June 2015) IP/15/5166 <http://europa.eu/rapid/press-release_IP-15 -5166_en.htm>.

98 Commission, 'Commission accepts commitments from Amazon on e-books' (n 1).

99 E-book MFNs and related matters (Case COMP/AT.40153) Communication from the Commission [2017] OJ C26/2, para 4.

100 For some recent numbers on e-book penetration, see Michael kozlowski, 'The State of the European eBook Market' (Good EReader, 16 March 2017) <http://goodereader.com/blog/e-booknews/the-state-of-the-european-ebook-market>; for the one billion dollar figure, see Commission, 'Commission accepts commitments from Amazon on e-books' (n 1).

101 E-book MFNs and related matters (n 99) para 3.

102 In the UK, Amazon is alleged to have a 95\% market share: Michael Kozlowski, 'Amazon Controls 95\% of the eBook Market in the UK' (Good E-Reader, 27 March 2015) <http://goodereader.com/blog/electronic-readers/amazon-controls-95-of-the-ebookmarket-in-the-uk>; in Germany, the number has been put at 50-60\%: Edward Nawotka, 'In Germany: Ebooks Less Than 10\% of Market, Tolino Grows' (Publishing Perspectives, 27 February 2015) <http://publishingperspectives.com/2015/02/in-germanyebooks-less-than-10-of-market-tolino-grows/>.

103 E-book MFNs and related matters (n 99) para 8 (emphasis added). parties, ${ }^{94}$ which has been confirmed in relation to MFNs. ${ }^{95}$ Secondly, the block exemption can be withdrawn when there are parallel networks of MFNs (supra) and when its effects are incompatible with Article 101(3) TFEU. ${ }^{96}$

\section{The Amazon E-books Case}

In June 2015, the Commission opened an investigation into Amazon's e-book distribution arrangements. The Commission focused on clauses in contracts between Amazon and its e-book suppliers (the publishers) that gave Amazon the right to terms and conditions at least as good as those offered to its competitors. ${ }^{97}$ The investigation ended with a commitment decision in which Amazon agreed to no longer enforce, introduce or change the terms of its agreements with publishers. ${ }^{98}$ Even though only a concise summary of the case is available, it does offer some new perspectives. Most interestingly, the case is based on Article 102 TFEU, ${ }^{99}$ while the Commission had previously assessed MFNs only under Article 101 TFEU.

While print book sales still vastly outnumber ebook sales, Europe's e-book market is worth more than one billion euros. ${ }^{100}$ In its investigation, the Commission separated the European e-book market per language, focusing on the relevant markets for the retail distribution of English and German language e-books to consumers in the EEA'. ${ }^{101}$ The Commission states that Amazon may be dominant in this market without offering information on its market shares, but the observation is in line with numbers circulating publicly. ${ }^{102}$ Now let us break down the clauses concerned - and the questions they give rise to.

Remember from the Apple e-books case that Amazon operated a classic wholesale model where it buys e-books and then resells them. These contracts included clauses

requiring the E-book Supplier to provide Amazon a wholesale price that depends [...] on the wholesale/agency price the E-book Supplier provides to any E-book Retailer other than Amazon, or the reseller price charged to consumers by any E-book Retailer other than Amazon. ${ }^{103}$

These clauses are classic but very broad wholesale MFNs, more specifically most favoured customer clauses. 
Amazon also included in its contracts clauses requiring the E-book Supplier to set an agency price on Amazon that depends [...] on the agency price set by the E-book Supplier (or charged by an E-book Retailer) on any E-book Retailer other than Amazon, or on the reseller prices charged to consumers by E-book Retailers other than Amazon. ${ }^{104}$

These clauses are retail MFNs, more specifically wide ones as they relate also to the retail price charged through other platforms.

Moreover, the clauses also ensured that Amazon received the most favoured selection, features, promotion, discounting and business model for the sale of e-books. ${ }^{105}$ Finally, Amazon imposed broad information obligations on e-book suppliers

requiring the E-book Supplier to notify Amazon if it makes available different alternative business models, e-books, availability dates, features, promotions or lower wholesale and agency prices to E-book Retailers other than Amazon. ${ }^{106}$

These clauses give rise to several questions. First of all, what about the commitment of the large publishers not to enter into agreements that contain MFNs for a period of five years $?^{107}$ The publishers involved are not identified, so do they exclude the large publishers, or did those publishers contravene the commitments entered into? Secondly, how do retail MFNs figure into Amazon's wholesale model for the distribution of e-books? Does this perhaps relate to self-publishers who do sell their e-books on Amazon through an agency model ${ }^{108}$ But most importantly, what can we learn from the (limited) assessment?

In putting forward theories of harm, the Commission sticks to established doctrine. It states that the wholesale MFNs ' may be capable of hindering E-book Retailers from entering and expanding in the relevant markets by offering lower e-book retail prices to consumers than Amazon'. ${ }^{109}$ With regard to the retail MFNs, the Commission holds that they may deter the entry or expansion of e-book retailers (thereby strengthening Amazon's dominant position) and reduce competition between e-book retailers allowing Amazon to charge higher commissions (which may ultimately lead to higher e-book retail prices). ${ }^{110}$

The final question is why the Commission considered Amazon's use of MFNs an abuse of dominance. Amazon may be dominant, but one could argue that this was the case with several of the undertakings previously investigated by NCAs. ${ }^{111}$ One may wonder whether the Commission finds Article 102 TFEU to be generally better suited, or just better suited in this case. The former scenario would be in line with the position of Akman, who argues that assessing MFNs under Article 102 TFEU is legally more appropriate and sound than under Article 101 TFEU. ${ }^{112}$ On the other hand, maybe it is the enormous breadth of the clauses that made the difference in this case, together with the fact there seems to be more of an imposition of the clauses (as opposed to agreement on them in the Apple e-books case).

\section{Recent and Future Developments}

MFNs are here to stay: a survey in the International Competition Network indicated that MFNs are a concern in the jurisdictions of half of its European members. ${ }^{113}$ The Amazon e-books case may not have given the answers some of them expected. The Commission also looked at MFNs in the framework of its Ecommerce Sector Inquiry, on which it recently issued a final report. ${ }^{114}$ The Commission offered mainly numbers on the prevalence of MFNs (they are fairly rare), but does not offer guidance beyond the fact that they 'have to be analysed and assessed on a caseby-case basis.' ${ }^{115}$ This is characteristic of the whole

\footnotetext{
104 ibid para 7 (emphasis added).

105 ibid paras 5-7.

106 ibid para 9

107 E-books (n 25) paras 101-2.

108 Amazon Author Central, 'Publishing and Selling on Amazon' $<$ https://authorcentral.amazon.com/gp/help/ref=AC_CU_Booksnotavail-oop-dyk?topicID $=200650270>$; the identified target group of this program includes independent authors and publishers with limited facilities or with new, unknown authors. These publishers set the price of their e-books themselves and give Amazon a 30\% Commission.

109 E-book MFNs and related matters (n 99) para 13.

110 ibid para 12; on these effects, see Chapter III.3.b.

111 These authorities stuck to art 101 TFEU (see Chapter III), although they have flirted with applying art 102 TFEU.

112 Akman ( $\mathrm{n}$ 48) 823-831; his main argument is that retail MFNs are only truly harmful in the presence of market power.

113 ICN, 'Online Vertical Restraints' (Special Project Report) 2015 68-70.

114 Commission, 'Final report on the E-commerce Sector Inquiry' (Staff Working Document) SWD(2017)154, paras 609-21.

115 ibid para 623.
} 
report, which is circumspect in identifying particular practices as problematic. ${ }^{116}$ In the mid-term review of its Digital Single Market strategy, the Commission did indicate that it will 'prepare actions to address the issues of unfair contractual clauses and trading practices identified in platform-to-business relationships', which 'could [...] take the form of a legislative instrument'. ${ }^{117}$

Earlier this year, the Commission issued a report on the monitoring exercise in the online hotel booking sector that it carried out in cooperation with ten NCAs. ${ }^{118}$ Summarising the results, the Commission states that the national enforcement activity has 'generally improved conditions for competition and led to more choice for consumers'. ${ }^{119}$ The heads of the European Competition Network also met to discuss the results, stating:

The results of the monitoring exercise suggest that both types of measure which are based on a converging theory of harm - on the one hand, allowing large online travel agents ('OTAs') to use socalled 'narrow MFN clauses' and, on the other, prohibiting OTAs from using MFN clauses - go in the right direction. ${ }^{120}$

However, holding that diverging courses of action based on a converging theory of harm go in the right direction is not exactly satisfying. Germany is well aware of its diverging position, and has sought to justify it by pointing to the specific nature of the German market and the failure of Booking.com to substantiate its efficiency claims before the Bun

116 Jay Modrall, 'EU Issues Final Report on its E-Commerce Sector Inquiry and Updates its Digital Single Market Plans' (Kluwer Competition Law Blog, 23 May 2017) <http://

kluwercompetitionlawblog.com/2017/05/23/eu-issues-final-report -e-commerce-sector-inquiry-updates-digital-single-market-plans/>.

117 Commission, 'Mid-Term Review on the implementation of the Digital Single Market Strategy' (Staff Working Document) $\operatorname{COM}(2017) 228,9$

118 Commission, 'Monitoring exercise carried out in the online hotel booking sector by EU competition authorities' (Report) $2017<\mathrm{http}: /$ ec.europa.eu/competition/ecn/hotel_monitoring_report_en.pdf>.

119 Commission, 'Commission publishes report on online hotel booking' (Daily News, 6 April 2017) <http://europa.eu/rapid/press -release_MEX-17-896_en.htm>.

120 Commission, 'Meeting of ECN DGs' (Outcome, 17 February $2017)<$ http://ec.europa.eu/competition/antitrust/ECN_meeting _outcome_17022017.pdf>.

121 Germany, 'OECD Hearing on across platform parity agreements' (Note) (n 23) 9-10.

122 art 133 Loi n² 2015-990 du 6 août 2015 pour la croissance, I'activité et l'égalité des chances économiques ('Loi Macron'); 99. deskartellamt. ${ }^{121}$ But while the German precedent was not followed by other European competition authorities, some legislators (notably in France and Austria) did successfully pursue a complete ban on MFNs between hotel portals and hotels. ${ }^{122}$ Considering their case strengthened by the recent Amazon e-books decision, interest groups are also pushing for regulation in other countries. ${ }^{123}$

All of which explains the calls for more guidance on the assessment of (particularly retail) MFNs. Some would have liked to receive this guidance through the e-commerce sector inquiry, but also see opportunity in a staff working paper. ${ }^{124}$ Others think that this guidance should be offered through enforcement decisions, ${ }^{125}$ and still others would prefer a referral to the CJEU. ${ }^{126}$ In any case, NCAs are not waiting: the CMA is currently carrying out an extensive market study on PCWs, ${ }^{127}$ while the Dutch Competition Authority has included retail MFNs in its enforcement priorities. ${ }^{128}$ Both competition authorities hint at the permissibility of narrow MFNs and indicate concern over wide MFNs.

\section{Conclusion}

Despite calls for more guidance, this article has argued that a framework for the assessment of MFNs is gradually taking shape. While scrutiny of wholesale MFNs continues, as demonstrated by the Amazon e-books case, their assessment is relatively straightforward. NCAs have had more trouble with

Bundesgesetz: Änderung des Bundesgesetzes gegen den unlauteren Wettbewerb 1984 - UWG und des Preisauszeichnungsgesetzes (the Austrian law on unfair competition).

123 See eg in Belgium: Werner Rommers, 'Hotels komen in opstand tegen Booking.com' (Nieuwsblad, 14 May 2017) <http://www .nieuwsblad.be/cnt/dmf20170514_02880831>.

124 Nicolas Sahuguet et al, 'Vertical Restraints: Towards Guidance to Iron Out Perceived Enforcement Discrepancies Across Europe?' (2016) 7 JECLAP 274, 279

125 Josefine Hederström and Luc Peeperkorn, 'Vertical Restraints in On-line Sales: Comments on Some Recent Developments' (2016) 7 JECLAP 10, 20.

126 Heinz (n 22) 536

127 The deadline is set for 28 September 2017, but an update paper is already available, see CMA, 'Digital comparison tools market study' <https://www.gov.uk/cma-cases/digital-comparison-toolsmarket-study>.

128 Authority for Consumers \& Markets, 'ACM's strategy and enforcement priorities with regard to vertical agreements', 22-3<https:// www.acm.nl/en/publications/publication/14226/ACMs-strategy -and-enforcement-priorities-with-regard-to-vertical-agreements/>. 
assessing retail MFNs. Still, the case law shows a lot more convergence than divergence, and - taken together - offers a blueprint for future cases. So while the Commission may have missed some recent opportunities for clarification, NCAs are in no way flying blind when assessing MFNs. 